\title{
Sobre a (in)xustiza xuvenil: da súa histórica vocación educativa e a intrusión da lóxica neoliberal
}

\author{
(Youth (in)justice: its educational mission and the incursion of \\ neoliberal logic)
}

\author{
Ana IGLESIAS GALDO \\ Universidade da Coruña
}

RESUMO: Baixo unha perspectiva xenealóxica sobre o noso sistema de xustiza xuvenil, pretendemos problematizar a intrusión da ideoloxía neoliberal na súa lóxica actual, ao entender que puidese deitar transparencia sobre as súas verdadeiras finalidades, requisito imprescindible para seguir avanzando nos dereitos da infancia da súa competencia, tan frecuentemente vulnerados. Utilizando como fontes discursivas, non tanto a actual lei formalmente aprobada nin as súas sucesivas modificacións, senón os discursos defendidos durante os debates parlamentarios o traballo organízase en tres apartados. Para comezar, búscase evidenciar en que termos se xustifica a actual regulación da responsabilidade penal para menores de idade, isto é, que estratexias se despregaron para conseguir 0 alto grao de consenso alcanzado; a continuación, profúndase sobre a súa histórica vocación educativa, co fin de valorar se responde a unha función de regulación e control social para esta mocidade ou, pola contra, procura garantir a aprendizaxe daquelas capacidades básicas que lles permitan recoñecerse como suxeitos de dereitos e deberes; por último, a modo de conclusión, reclámase a urxente necesidade de dicir a verdade, debatendo en profundidade sobre que tipo de políticas garantirían a este colectivo xuvenil que a súa xustiza fose xusta.

PALABRAS CHAVE: juventud; educación; responsabilidade penal; neoliberalismo; (in)xustiza.

ABSTRACT: The article problematises the intrusion of neoliberal ideology on our juvenile justice system from a genealogical perspective, in order to expose the privileging of neoliberal interests over the so-often neglected rights of children and young people. The analysis focuses not on the Criminal Responsibility of Minors Act and its successive modifications currently in force, but on the parliamentary speeches made in defence and justification of the new law. The article is divided into three sections, the first of which examines the justification offered for the regulation of criminal responsibility for minors and the strategies deployed to obtain consensus. The second section assesses the historical commitment of the youth justice system to education, to determine whether the purpose of the model is to monitor and regulate young people's actions and behaviour, or to ensure they acquire the basic abilities they need to recognise themselves as legal subjects with rights and responsi- 
bilities. The article concludes by highlighting the urgent need for an honest, comprehensive debate about the type of policies needed to guarantee fair justice for young people.

KEYWORDS: young people; education; criminal responsibility; neoliberalism; (in)justice.

\section{Introdución a modo de contextualización}

É hora de pensar ao revés: de definir os cambios que se deben realizar partindo do fin último ao que se quere chegar e non os fins partindo dos medios dispoñibles, do parches inmediatamente realizables. ${ }^{1}$

Aínda que é certo que en todas as épocas históricas algunha mocidade cometeu delitos e recibeu por iso diferentes sancións, na maior parte deses países europeos - tamén en España-, as orixes dunha xustiza especializada de menores está intimamente vinculada a procesos de industrialización e urbanización, a novas formas de socialización familiar e escolar, á regulación cada vez máis pormenorizada da vida social ou á progresiva delimitación da infancia e a mocidade en canto categorías sociais específicas, así como aos saberes que se ocupan do seu estudo.

É nos albores do século XX, coa cuestión social do pauperismo, á que se respondía con novos sistemas de control dirixidos especialmente sobre a infancia e xuventude que sufrían con especial virulencia os efectos dun capitalismo incipiente e que, ao quedaren situadas fóra das principais institucións socializadoras, cando se viu necesario crear unha alternativa que, en nome da educación, asegurase o seu control, a aprendizaxe dos valores burgueses e a aceptación de oficios proletarios: Lei de tribunais especiais para nenos (1918).

0 chamado dereito protector dos menores delincuentes, apoiado nos principios do positivismo e do correccionalismo, asume a incapacidade dos menores para seren culpables e, por tanto, a consideración destes como irresponsables penalmente, como xa anunciara Dorado Montero (1915), un dos seus principais impulsores: "un dereito penal semellante, que non necesita para existir delito nin pena, é o que a fume de carozo se nos bota enriba". ${ }^{2}$

Os principais postulados do modelo tutelar continuarán tamén activos nas principais reformas, e e no texto refundido da lexislación sobre tribunais tutelares de menores do 11 de xuño de 1948 (baixo o réxime franquista e vixente na súa totalidade ata principios do noventa). ${ }^{3}$

\footnotetext{
${ }_{1}^{1}$ André Gorz, Miserias del presente, riqueza de lo posible (Barcelona: Paidós, 1998), 81.

2 Pedro Dorado Montero, El derecho protector de los criminales (Navarra: Jiménez Gil Editor, 1999) (Orixinal publicado en 1915, Madrid: Librería General de Victoriano Suárez), 231.

${ }^{3}$ Malia que anteriormente á aprobación desta lei existían disposicións especiais para a protección e a custodia da infancia delincuente que tomaban en conta a inmadurez e a incapacidade dos menores - tal e como se evidencia nos sucesivos códigos penais que foron aparecendo desde 1822-, será agora cando a minoría de
} 
A declaración parcialmente inconstitucional da Lei de tribunais tutelares de menores (1948), pola sentenza 36/1991, será a que motive na Lei 4/1992, do 5 de xuño, sobre reforma da lei reguladora competencia e o procedemento dos xulgados de menores, tanto o seu carácter de reforma urxente (non contén máis de tres follas), como tamén a súa transitoriedade, á espera dunha renovada lexislación sobre reforma de menores. Como principais novidades con respecto á de 1948 destacamos, con Bernuz-Beneitez: a introdución do principio de proporcionalidade entre o feito cometido e a medida imposta; a esixencia de tipicidade penal que supón a distinción entre 0 sistema da xustiza de menores e o sistema de protección infantil; a definición dunha idade mínima —-doce anos- por baixo da cal os menores son presuntos non culpables de transgredir as leis penais; a definición dunha idade máxima (16 anos) a partir da cal os autores das infraccións cometidas son reenviados á xurisdición penal ordinaria. ${ }^{4}$

A teor do exposto, podemos afirmar que a Lei orgánica 5/2000, do 12 de xaneiro, reguladora da responsabilidade penal de menores (LORRPM) é a primeira iniciativa da democracia española para estruturar globalmente a xustiza de menores e tamén a primeira vez que a regulación da responsabilidade penal se asume no seu título, sen complexos. Neste recentemente estreado século XXI onde o neopauperismo, en forma de exclusión, se constitúe na nova cuestión social e apunta novamente a aquela mocidade máis vulnerable socialmente que, por non permanecer ligada a ningunha das institucións sociais recoñecidas (familia, instituto ou traballo), é redefinida como un perigo para a sociedade, situada no ámbito da seguridade persoal e destinataria dun proxecto pedagóxico de carácter sancionador que xustifica democraticamente as medidas deseñadas para o seu control.

En síntese, a histórica combinación de protección e castigo baixo o discurso educativo, é a principal xustificación para a especialización da xurisdición de menores separada da das persoas adultas, aínda que atravese distintas fases: a etapa clásica da lexislación penal baseada no concepto de inimputabilidade, a etapa tutelar que introduce 0 criterio cronolóxico fronte ao de discernimento e non esixir responsabilidade penal a estes menores por consideralos necesitados de protección, e unha terceira, a actual, que introduce a regulación da responsabilidade penal de menores.

0 noso actual ordenamento xurídico regula a minoría de idade penal no Código penal (CP) e na LORRPM á que remite 0 devandito CP. Desde a súa aprobación chama a

idade adquira primacía sobre os feitos, no momento da súa valoración xurídica. 0 estatuto de menor delincuente como plenamente irresponsable imponse tras a anulación do criterio de discernimento e a emerxencia do criterio cronolóxico que introduce o Código penal de 1928, que sitúa nos 16 anos a idade a partir da cal se pode responder penalmente, polo que os menores desa idade non poden ser imputados, e dada a súa condición de irresponsables deberán ser sometidos á xurisdición especial do tribunal tutelar para nenos. A responsabilidade penal fíxase nos 16 anos, pero terá un carácter atenuado ata os 18. Esta regulación pasou ao código de 1932 e deste ao de 1944 e á súa seguinte redacción de 1973. Coa aceptación deste criterio, que estará vixente ata a entrada en vigor do Código penal de 1995, os menores permaneceron excluídos do dereito penal de adultos, mais tamén ficaron fóra das garantías individuais.

${ }^{4}$ María José Bernuz-Beneitez, "L'évolution de la justice des mineurs en Espagne", Déviance et Société 26, n. ${ }^{\circ}$ 3 (2002): 343-353. 
atención, ademais das numerosas modificacións e do seu progresivo endurecemento, un estado de opinión xeneralizado que, impactado por algúns casos estatisticamente minoritarios pero que suscitan grande alarma social, continúa pondo en dúbida a súa efectividade e reclama unha maior contundencia e control sobre esta poboación como a única opción que pode impedir a reincidencia. Neste contexto de violencia imaxinaria, propia da chamada risk society, ${ }^{5}$ Ionxe de pór en cuestión 0 cambio da súa racionalidade, isto é, o seu actual carácter penal, demándanse con máis forza políticas de tolerancia cero caracterizadas por esixiren castigos rápidos e rotundos para previr a delincuencia que, á súa vez, lexitiman un maior abano de medidas para aplicar e xeran unha ampliación do control social sobre este colectivo xuvenil. ${ }^{6}$

Defender como urxente necesidade esixir responsabilidade penal para mellorar a xustiza xuvenil é unha opción lexítima, pero convén preguntarse: de que diagnóstico se parte para facer estas propostas e non outras? Cales son os problemas, necesidades ou conflitos que se pretenden resolver? Reclámanse con suficiente forza os dereitos sociais e económicos para esta mocidade? É necesario que esta lexislación alcance a outras institucións sociais como a escola, os servizos sociais, de vivenda ou mesmo sanitarios? Que finalidades se lle outorgan á educación? En definitiva, preguntámonos con Rangugni, "Que fai, pois, a xustiza de menores?, castiga, educa, axuda?, a quen axuda, ao menor, á familia, á vítima?".

Baixo unha perspectiva xenealóxica sobre o noso sistema de xustiza xuvenil, pretendemos problematizar a intrusión da ideoloxía neoliberal na súa lóxica actual, ao entender que puidese deitar transparencia sobre as súas verdadeiras finalidades, requisito imprescindible para seguirmos avanzando nos dereitos desta infancia tan vulnerada socialmente. Utilizando como fontes discursivas, non tanto a actual lei formalmente aprobada nin as súas sucesivas modificacións, senón os discursos defendidos durante os debates parlamentarios, procuramos evidenciar algunhas das estratexias utilizadas para conseguir, cunha grande aceptación social, a regulación da responsabilidade pe-

\footnotetext{
${ }^{5}$ Ulrich Beck, La sociedad del riesgo. Hacia una nueva modernidad (Barcelona: Paidós, 1998).

${ }^{6}$ A LORRPM foi aprobada 012 de xaneiro de 2000 e entrou en vigor un ano despois da súa publicación, 013 de xaneiro de 2001. 0 artigo 1 da LORRPM establece que será aplicable para esixir responsabilidade ás persoas maiores de 14 anos e menores de 18 pola comisión de feitos tipificados como delitos ou faltas no Código penal ou leis penais especiais (aínda que convén lembrar que, en virtude da reforma da L0 1/2015, do 30 de marzo, as faltas desapareceron do Código penal, polo que se supón debería ser novamente reformada). É dicir, os menores de 14 anos e aqueles que teñen unha idade comprendida entre os 18 e os 21 (desde a modificación introducida na L0 8/2006), non son competencia desta lei. É unha lei que xa antes da súa entrada en vigor foi modificada por dúas leis aprobadas o mesmo día, e foi obxecto de diversas modificacións posteriores que evidencian un gradual endurecemento das medidas. Sobre as súas modificacións e o progresivo endurecemento das súas medidas, resultan moi esclarecedores os traballos de María José Jiménez Díaz, "Algunas reflexiones sobre la responsabilidad penal de los menores", Revista Electrónica de Ciencia Penal e Criminología n. ${ }^{0} 17-19$ (2015): 1-36, así como o de María José Bernuz-Beneitez, "Justicia de Menores Española y nuevas tendencias penales. La regulación del núcleo duro de la delincuencia juvenil”, Revista Electrónica de Ciencia Penal y Criminología n. ${ }^{\circ} 07-12$ (2005): 12-23.

${ }^{7}$ Victoria Rangugni, "Algunos aspectos de la 'nueva' justicia de menores", Panóptico. Revista Monográfica Semestral de Crítica a la Política Criminal 4 (1997): 8.
} 
nal para menores de idade; tamén profundar sobre a súa histórica vocación educativa, co fin de valorar se responde a unha función de regulación e control social para esta mocidade ou, pola contra, busca garantir a aprendizaxe daquelas capacidades básicas que lles permitan recoñecerse como suxeitos de dereitos e deberes; e, por último, reclamar a urxente necesidade dun debate pendente para dicir a verdade e debater en profundidade sobre que tipo de políticas garantirían a este colectivo xuvenil que a súa xustiza sexa xusta.

Considerando que 0 castigo é un dos elementos definitorios das sociedades, comezamos achegándonos á linguaxe con que se sostén, á lóxica que o lexitima, isto é, ao que Michel Foucault conceptualizou como a gramática do castigo, baixo a pretensión de evidenciar algúns dos seus inxustos efectos e pórnos en acción para camiñar en sentido contrario.

\section{A defensa da responsabilidade penal baixo un discurso sedutor e cheo de boas intencións}

Non teñas problemas de conciencia: o mal é polo seu ben.

El Roto

As leis adoitan ser pensadas pola maior parte da poboación como necesarias e tamén xustas; exactas, logo desinteresadas. Este sentido común leva a crer que aquelas poderían ser melloradas, pero a súa esencia, no sentido de se cuestionar a quen benefician, baixo que ideoloxía se arroupan ou mesmo a que intereses responden, semella non someterse a discusión, o que implica negarlles, dalgún xeito, o seu carácter político.

Baixo este suposto socialmente asumido, polo menos por unha boa parte da cidadanía, descansa a certeza de que as leis referidas a menores que cometen actos que, de seren maiores serían considerados como delitos, deben regular a súa responsabilidade penal; 0 que á súa vez explica que non se esixa un debate profundo sobre os posibles efectos discriminatorios que puidesen derivar da aplicación das medidas sancionadoras e, moito menos, preocupe ou se chegue a cuestionar baixo que ideoloxías se lexitima a actual regulación da responsabilidade penal para menores.

Durante as sesións dos debates parlamentarios do proxecto da LORRPM, que sustenta o marco actual, preséntase a súa defensa como un desafío, un proxecto de lei necesario, urxente e moderno, afastado da vella lexislación protectora, e ao que se lle imprime carácter de urxencia, por ser vista como a única alternativa posible, sensata e viable. ${ }^{8}$

\footnotetext{
${ }^{8}$ Proxecto de lei orgánica reguladora da responsabilidade penal dos menores, Congreso 25 de febreiro de 1999, n. 217 (pp. 11606-11625); Proxecto de lei orgánica reguladora da responsabilidade penal dos menores, número de expediente 121/000144, Congreso 11 de novembro de 1999, n. ${ }^{0} 270$ (pp. 14449-14459); Proxecto de lei orgánica reguladora da responsabilidade penal dos menores, número de expediente 121/000144, Congreso. 22 de decembro de 1999, n. ${ }^{0} 283$ (pp. 15269-15278).
} 
Quen podería estar en desacordo con esta filosofía? Quen non defendería unha transformación profunda do ámbito da xustiza xuvenil que garantise a este colectivo que "a súa xustiza" fose xusta? En definitiva, que sentido teñen estas palabras? Quizais sexan, unha vez máis, unha simple declaración de principios, na liña destacada polo profesor Emilio Lledó: "Prodigáronse tanto estas palabras, en tan diversas ocasións, en tan opostos contextos, que xa non son utópicas. Son absolutamente tópicas: pelouros traballados pola historia, consolo, en definitiva, da ignorancia, da inconsciencia ou de mala fe". ${ }^{9}$

Para descubrir o verdadeiro significado dos conceptos utilizados neste proxecto de lei, escoitamos os argumentos esgrimidos na súa defensa, e axiña comprobamos como o problema social que se presenta como de urxencia para resolver é, xunto co de evitar a reincidencia, o derivado dunha reforma pendente a nivel xurídico. Ningunha das ideoloxías políticas presentes na Cámara dubidou da necesidade dunha reforma lexislativa neste ámbito, pois efectivamente, tal e como defenden diferentes representantes políticos, desde que o Código de 1995 elevase a maioría da idade penal dos 16 aos 18 anos, facíase necesaria unha futura lei reguladora da responsabilidade penal dos menores, unha resposta xurídica para os feitos delituosos cometidos por menores de 18 anos; isto é, a principal xustificación para explicar 0 carácter de urxencia é o feito de estar paralizada a aplicación do Código penal para os menores de 18 anos; aínda que non era esta a única opción posible, pois podería aceptarse a modificación deste último e defender a posibilidade de esixir outro tipo de responsabilidade a este colectivo xuvenil.

Decidir ata que idade unha sociedade está disposta a prescindir dunha intervención penal ${ }^{10}$ é un asunto de política criminal pois, como ben explica Giménez-Salinas, a valoración da mocidade en relación coa súa inimputabilidade ou imputabilidade, é unha cuestión que remite ás finalidades do sistema de xustiza xuvenil, ás súas funcións e, por tanto, tamén a cuestións éticas. ${ }^{11}$

Ao achegarnos ao tipo de argumentario que sostén a defensa deste carácter penal, descubrimos que a coacción innata á súa lóxica desaparece baixo un discurso. Así, un tipo de linguaxe cargada de boas intencións e positivade que, coma se de "palabras máxicas" se tratase, lonxe de xerar mala conciencia entre aqueles que 0 defenden, fano con orgullo, sen complexos, coma se fosen incapaces de percibir ningún dos posibles efectos inxustos sobre as infancias obxecto deste proxecto. ${ }^{12}$

\footnotetext{
${ }^{9}$ Emilio Lledó, Sobre la educación. La necesidad de la literatura y la vigencia de la Filosofía (Barcelona: Taurus, 2018), 193.

${ }^{10}$ Como xa fomos expondo, segundo a Lei dos tribunais tutelares de menores de 1948, os menores non eran considerados responsables penalmente ata os 16 anos; coa Lei 4/1992, os xulgados de menores teñen competencia nos casos de delincuencia de menores de entre 12 e 16 anos, pero sen lles esixir responsabilidade penal; e a Lei 5/2000 establece a súa competencia nos menores de 14 a 18 anos, regulando a súa responsabilidade penal.

${ }^{11}$ Esther Giménez-Salinas i Colomer, dir., Legislación de menores en el siglo XXI: análisis de derecho comparado (Madrid: Consejo General del Poder Judicial, 1999), 101.

12 Das opinións vertidas nos debates parlamentarios, seleccionamos as que, ao noso criterio, ao noso criterio, evidencian os principais argumentos esgrimidos desde os diferentes partidos políticos.
} 
Entendemos que é correcta a denominación de lei penal xuvenil (...) Parécenos que 0 adxectivo penal non supón demérito na actitude proteccionista, senón que, moi ao contrario, introduce elementos de garantía que van en ben do dereito de defensa dos menores sometidos ao imperio desta lei (11-XI1999, GV).

0 meu grupo non se escandaliza de que sexa unha lei penal (...) 0 que trata é de lle achegar un sentido de responsabilidade, de flexibilidade, de sentido común e de intelixencia (11-XI-1999, CC).

Cremos que con esta lei se vai eliminar a dor e a frustración de tantos nenos da rúa, de tantos adolescentes recluídos sen futuro que nestes momentos se atopan en España (...) Estamos convencidos de que este non é un texto represor, ao contrario, é un texto educativo e sancionador, realista, coherente e con rigor, que vai liquidar un problema que 0 goberno socialista nunca foi capaz de solucionar en catorce anos (22-XII-1999, PP).

Este é un típico proxecto de lei penal xuvenil en que á comisión dun feito tipificado como delito ou falta lle corresponden unhas consecuencias xurídicas de carácter sancionador. Que estas consecuencias xurídicas de carácter sancionador teñan un contido primordialmente educativo non altera para nada este carácter penal, recoñezámolo e non nos avergoncemos (11-XI-1999, PSOE).

Mantén os efectos de exemplaridade nunha sociedade que se rexe por unhas normas, onde a penalización non é unha cuestión que menoscabe un dereito constitucional lexítimo e si unha garantía pertinente nos que se trata de corrixir (22-XII-1999, CC).

Sobre o uso específico da linguaxe na defensa deste proxecto, poboada de diferentes eufemismos e de evidentes contradicións, resulta brillante 0 argumentario exposto polo parlamentario de Esquerda Unida, o deputado Castellano Cardalliaguet:

Vén por fin a esta Cámara, sen ningunha clase de eufemismos, o proxecto de LORRPM. Non os hai en admitir que é penal, pero si está chea de eufemismos para xustificalos (25-II-1999, EU).

Deixémonos de eufemismos. Escolleuse a xurisdición penal de menores e paréceme tan lexítima como calquera outra posición. 0 que non parece lexítimo é que isto se comece a decorar cun conxunto de argumentacións que non teñen sustentabilidade (...) Aquí hai unha diferenza radical de filosofía (...) o que estamos a facer é sinalar a idade penal dos nosos cidadáns aos 13 anos e, iso si, coa terminoloxía máis florida procurar que non pareza que perseguimos os menores (...) Mantemos a nosa filosofía de que isto non é unha lei tuteladora, protectora, comprensible e moderna dese fenómeno que se chama delincuencia xuvenil, porque ten de substantivo 0 xuvenil e, de adxectivo, 0 de delincuencia. Gustaríanos unha lei que non tivese nada que ver co xurisdicional e o penal. Unha lei en que falásemos da responsabilidade social cando un menor aparece inmerso (...) Innovaron vostedes no eufemismo. Eu procurarei extraer a terminoloxía non xa ambigua, nalgúns casos hipócrita, que rodea a este proxecto para ir acrecentando a miña riqueza terminolóxica (25-II-1999, EU).

Hai unha responsabilidade penal dos menores. Eu sei que falar de responsabilidade penal dos menores e asomarse a este proxecto de lei ten que obrigar a algúns, cunha enorme mala conciencia, a acudir a eufemismo: chamémoslle doutra maneira, disimulémolo como poidamos. Non o disimulemos máis. Hai responsabilidade penal para os menores. Hai un procedemento sancionador (...) hai restrición á liberdade de menores. Hai medidas que afectan aos seus dereitos. Isto é un proceso penal do menor (11-XI-1999, EU).

Afastada da defensa dos catro des (D) propostos para esta xurisdición especializada pola Convención das Nacións Unidas sobre os Dereitos dos Nenos (despenalización, desinstitucionalización, proceso xusto [<due process] e desxudicialización), a ideoloxía 
neoliberal, baleirada da súa dimensión moral e ética, ${ }^{13}$ incorpora a filosofía penal ao ámbito de menores, aínda que en ocasións a negue e noutras, como ben explica Bernuz-Beneitez, a xustifique pola súa función meramente simbólica, pretendendo dar a sensación tranquilizadora (ou sedante) de que estamos ante una lexislación atenta ás demandas e esixencias sociais. ${ }^{14}$

A pesar de que se está a propor un novo modelo lexislativo que muda substancialmente a lóxica dominante ata ese momento, é presentado como a única opción posible, realista e de sentido común; pechando con certo resaibo autoritario un debate pendente sobre a conveniencia ou non de sacar definitivamente á mocidade da lóxica penal:

Pódense comparar co texto socialista de 1992. Pódense comparar os textos, son perfectamente intercambiables. Só hai unha diferenza: que naquela época tiñamos debate acerca de se conviña falar da xudicialización do proceso de menores en aras á súa imputabilidade ou pola contra, como nós mantiñamos, debiamos falar da corrección dos menores que participaban en feitos que de seren cometidos por maiores de idade serían delito (25-II-1999, n. ${ }^{0} 217$, EU).

É de salientar que, aínda que moi minoritariamente, se expuxeron outras opcións igual de posibles e, ao noso entender máis xustas e realistas, apelando a unha xurisdición socioadministrativa que excluíse do ámbito do dereito penal a menores de idade. ${ }^{15}$

Hai outras opcións. Outra filosofía (...) Nós, no canto de optar pola xudicialización, teriamos ido polo camiño da administrativización. Pero como a maioría da Cámara optou por esta forma de tratamento (...) Unha lei que fai descender a responsabilidade dos menores aos 14 anos. Esta lei desdí categoricamente toda unha filosofía no que respecta ao que é o principio de imputabilidade e da inimputabilidade (11-XI-1999, n. ${ }^{0} 270$, EU).

E é de destacar, tamén, outras voces discrepantes que, cunha maior ou menor énfase defenderon a posibilidade de desposuíla definitivamente do carácter penal, e buscar outra resposta máis inclusiva para este tipo de comportamentos comportamento, ao entender que podería ser unha oportunidade para avanzarmos en dereitos e non en novas ou renovadas sancións. Así se defende:

Nós non queremos un código penal, senón que sexa 0 artigo que impida que os menores cheguen a pasar ao Código penal (25-II-1999, GMixto).

A súa natureza non debe ser penal. Debía ter dado un paso moito máis audaz en canto a despexarse por completo do carácter penal. Non debería chamarse de responsabilidade penal do menor, senón de responsabilidade sancionatoria ou de xustiza xuvenil (...) porque estamos ante un obxecto fundamentalmente educativo. Non é un proxecto de natureza penal, é doutra natureza (11-XI-1999, NI-IC).

\footnotetext{
${ }^{13}$ Richard-Alexandre Laniel et Max Silverman, "Justice néolibérale: quand la logique du marché intègre les institutions judiciaires", Nouvaux Cahiers du socialismo 16 (2016): 43-50.

${ }^{14}$ Bernuz-Beneitez, "La justicia de menores y las nuevas tendencias penales", 12.

${ }^{15}$ As fontes do propio Ministerio evidencian que a maior parte das infraccións cometidas por menores de idade pon de manifesto tanto o seu carácter episódico, como a escasa incidencia sobre os intereses da sociedade no seu conxunto.
} 
Baixo a ideoloxía de pensamento único que funciona como "réxime de verdade", ${ }^{16}$ obstaculizando a necesaria deliberación democrática sobre outras alternativas factibles para un renovado marco xurídico, afastándoa da profundidade necesaria das cuestións ético-políticas, e redirixíndoa cara a asuntos organizativos, de funcionamento e de xestión; como garantía de estabilidade, eficacia e rigorosidade:

Procedemento áxil, rápido con todas as garantías procesuais (25-II-1999, PP).

Estamos convencidos de que este non é un texto represor, ao contrario, é un texto educativo e sancionador, realista, coherente e con rigor, que vai liquidar un problema que o goberno socialista nunca foi capaz de solucionar en catorce anos. (22-XII-1999, PP).

Sobre esta proposta, presentada como única alternativa viable para mellorar a xustiza xuvenil, chama poderosamente a atención 0 amplo consenso ante 0 que é un cambio radical na política da xustiza xuvenil, por facer desaparecer a inimputabilidade a menores de dezaoito anos e maiores de catorce; e tamén ante a falta de evidencias científicas, de investigacións que, a modo de diagnóstico sobre este ámbito, puidesen achegar información imprescindible para para posibilitar un novo modelo de xustiza para esta xuventude.

De todas as estratexias utilizadas para conseguir un alto grao de conformidade na incorporación da responsabilidade penal, destaca tamén a táctica de reorientar insistentemente 0 debate cara á súa tamén natureza educativa, coma se polo feito de nomear esta, puidese desaparecer aquela, asunto ao que dedicaremos o seguinte apartado.

Garantir o consenso reorientando o debate cara á histórica "vocación educativa": rehabilitar, responsabilizar, recuperar, resocializar, reeducar

0 Estado neo-liberal non debe reeducar, resocializar, corrixir ou previr como o tiña asumido o Estado social. Así a todo, ha de configurar o seu sistema penal con base nunha nova verdade, nuns novos fins. Estes son os estritamente orientados á punición; é dicir, que unicamente debe punir, pero non só punir exemplarmente cada violación da nova orde, senón que mesmo ha de chegar ata o punto de crear alarma social para se converter en fonte de consenso ao redor das institucións, e prever así calquera eventual disentimento político. ${ }^{17}$

Desde a pedagoxía da xustiza, orientada a posibilitar o exercicio dun estatuto forte de cidadanía "educar é crear liberdade, dar posibilidade, facer pensar... é cultivar unha forma libre, creadora e insumisa — quero dicir crítica — de apropiación intelectual... A

\footnotetext{
${ }^{16}$ Michel Foucault, Microfísica del poder (Madrid: La Piqueta, 1992, 3. ${ }^{\text {a ed). }}$

${ }^{17}$ Roberto Bergalli, "Globalización y control social: post-fordismo y control punitivo", Sistema. Revista de Ciencias Sociales 160 (2001): 124.
} 
educación dun ser humano concreto é o desenvolvemento coherente dunha serie de posibilidades que o leven á realización dunha personalidade libre, autárquica e solidaria" ${ }^{18}$

Pero fronte a esta visión, propia das pedagoxías disruptivas, ${ }^{19}$ que defende educar ás persoas para constituirse en axentes individuais e sociais críticos e comprometidos; a ideoloxía neoliberal, utilizando a educación como estratexia de despolitización, socava 0 fundamento democrático da solidariedade, degrada a colaboración e rompe con todas as formas de obriga social que garanten o ben común. Esta forma de pedagoxía - característica do modelo da cultura punitiva-, faise evidente no debate que nos ocupa a través do vocabulario educativo utilizado que, ao lelo no seu conxunto —-mesmo aínda cando se repite-, emerxe con total transparencia o modelo de pensamento que a sostén:

Segue un proceso sancionatorio que se preocupa, por encima de todo, do interese do menor, da súa rehabilitación, do aspecto educativo, das súas circunstancias persoais e onde xoga, non ten ningún papel, 0 aspecto retributivo ou vindicativo (22-XII-1999, NI-IC)

A filosofía do proxecto de lei dunha responsabilidade penal do menor non é penalista, é unha filosofía pensada para a rehabilitación, pensada para a reeducación; é o único interese (22-XII-1999, NI-IC).

Incorpora unha nova política criminal e un novo modelo de xustiza xuvenil fundamentado en dous principios que nos parecen esenciais, como son, a reeducación do menor e a responsabilidade deste para conseguir previr futuras infraccións e un desenvolvemento equilibrado e maduro do menor e do mozo. (...) Afástase do dereito penal e é máis resocializador e máis consecuente co perfil do menor e coas súas circunstancias persoais, e as medidas para aplicar sen dúbida son medidas sancionadoras educativa. (22-XII-1999, PP).

0 que se tenta é recuperar, resocializar, reeducar o menor (22-XII-1999, PP).

Urxe acordar unha norma adecuada, coherente e con rigor, que en todo momento defenda os intereses dos menores infractores e que se fundamenta en dous alicerces: a educación para recuperar o menor e mozo infractor e a asunción da responsabilidade por parte destes menores e mozos, de tal maneira que se produza un desenvolvemento maduro e equilibrado da súa personalidade (...). Un sistema xudicial elaborado con seriedade, con rigor e con coherencia, que vai contar cun equipo multidisciplinar e que o que vai perseguir é a recuperación do menor (11-XI-1999, PP).

0 obxectivo non é 0 vindicativo, non é o castigo, non é a retribución, senón que o obxectivo é a educación. 0 seu obxectivo é a educación. 0 fundamental é protexer 0 interese do menor (11-XI-1999, $\mathrm{NI}-\mathrm{IC})$.

Todas as respostas son de tipo educativo (...). Non é un proxecto sancionador, é un proxecto educativo e recuperador (25-II-1999, PP).

Non queremos que este proxecto de lei sexa un código penal de menores (...). 0 texto ten rigor, ten unha finalidade recuperadora e educativa dos menores infractores. (...) Consideramos que a mellor medida sancionadora do menor é a social e educativa (25-II-1999, PP).

Cremos que este é un bo texto que ten a capacidade de recuperar e resocializar estes menores infractores (25-II-1999, PP).

\footnotetext{
${ }^{18}$ Lledó, Sobre la educación, 10, 197, 242.

${ }^{19}$ Henry A. Giroux, "Pedagogías disruptivas y el desafío de la justicia bajo regímenes neoliberales", Revista Internacional de Educación para la Justicia Social (RIEJS) 4, n. ${ }^{0} 2$ (2015): 13-27.
} 
A acción máis eficaz radica no fomento da autodisciplina e 0 sentido da responsabilidade máis que na coacción e o difuso concepto de prevención xeral (25-II-1999, PP).

Rehabilitar, recuperar, responsabilizar, resocializar, reeducar...(se) Finalidades que reenvían a certo tipo de dispositivos pedagóxicos en que, como explica Larrosa "0 importante non é que se aprenda algo 'exterior', un corpo de coñecementos, senón que se elabore ou reelabore algunha forma de relación reflexiva do 'educando' consigo mesmo", e por esta razón, continúa 0 autor "no vocabulario pedagóxico (...) esas formas de relación do suxeito consigo mesmo poden expresarse case sempre en termos de acción, cun verbo reflexivo". ${ }^{20}$

Unha longa listaxe de verbos co prefixo re- que, en palabras de Cerbino "adquiriron a característica innegable do lugar común, dado que no momento de profundar nas perspectivas, ningunha institución que os emprega sabe non só 'como', senón sobre todo desde 'onde', é dicir desde que referentes, valores, contidos novos e dalgunha maneira claros, volver partir" ${ }^{21}$

Poñendo 0 acento na actividade cognoscitiva sobre este sector da mocidade, á marxe do fracaso das institucións socioeducadoras das que forman parte, reclámase un equipo de profesionais que busquen indicios para coñecer os motivos que levan a esta mocidade a delinquir e poder así deseñar unha rápida solución: ${ }^{22}$

Si. Ten moito de educativo (...) fíxase no art. 7 como as medidas sempre o serán en interese do menor e con finalidade educativa (...) incluso dando a posibilidade a non incoar un expediente cando se comprobe que 0 interese do menor esixe que nin sequera se aplique (...) Permítese o libre xuízo do ministerio fiscal (...) tendo en conta o informe do equipo técnico e o perfil do menor (...) Execución das medidas (...) a posibilidade de reducir a súa duración, a súa substitución ou mesmo a súa suspensión, sempre tendo en conta os informes do equipo técnico, o interese do menor e o seu perfil (25-II-1999, PP).

Esta lei dá unhas garantías técnicas ao esixir neses tribunais unha especialización alta (...) Onde ten que haber un concurso de psicólogos, de psiquiatras, expertos en conduta infantil para entender que grao de pena pode imporse ao menor (25-II-1999, CC).

Recóllese a posibilidade de que, aínda existindo delito, poderá instar o ministerio fiscal a que non se apliquen as ditas medidas con base nas circunstancias e no perfil do menor (...) sempre en interese do menor e na súa defensa (25-II-1999, PP).

É a única forma de recuperalo e reeducalo nuns centros adecuados e cun equipo técnico en condicións (11-XI-1999, PP).

0 Equipo técnico é un órgano esencial nesta lei (...) coñécese a realidade do menor en todos os campos. (11-XI-1999, PP)

\footnotetext{
${ }^{20}$ Jorge Larrosa, coord., Escuela, poder y subjetivación (Madrid: La Piqueta, 1995), 261, 264.

${ }^{21}$ Mauro Cerbino, Jóvenes en la calle. Cultura y conflicto (Barcelona: Anthropos, 2006), 15-16.

${ }^{22}$ No contexto actual, esta lóxica podería remitir tamén á do adestramento deportivo, centrada en conseguir resultados visibles e a curto prazo e, baixo esta conceptualización, o equipo de profesionais especializados na problemática do menor concíbese tamén coma se de adestradores persoais se tratasen.
} 
Resoa, a modo de estéreo, o eco das reflexións de Dorado Montero, cando hai un século insistía na necesidade de pór a énfase non no delito cometido, senón na situación de cada delincuente, polo que cobraba especial importancia toda a vida pasada do menor e así poder iniciar o camiño cara á súa corrección. Ademais, faise evidente tamén unha liña de continuidade na conceptualización dos reformatorios como institutos pedagóxicos (seguindo o éxito do modelo das institucións americanas para a infancia delincuente, máis concretamente 0 reformatorio de Elmira), tal e como os concebía:

Unha nota característica do reformatorio como toda institución pedagóxica que con xustiza mereza tal nome é que se persiga de verdade a formación do espírito e do carácter dos educandos, nomeadamente: confiar, para a obra da educación e os seus bos resultados, principalmente na vontade do pupilo, na súa cooperación eficaz e activa, ao relegar a un segundo termo a intervención dos resortes exteriores, ao se servir deles como excitantes para espertar aquela (...) só ao entrar no reformatorio sabe que del depende a súa sorte. ${ }^{23}$

"Educación baixo mandato xudicial" foi a expresión utilizada por Donzelot para explicar esa solución secular de clara orientación psicolóxica, especificamente en termos terapéuticos que, ao asumir a premisa de localizar a posibilidade de cambio no interior do menor, as finalidades circunscríbense exclusivamente á "intervención sobre o menor", coma se fose un asunto de aprendizaxe de destrezas, 0 cal favorece así a psicoloxización dos problemas sociais e a súa despolitización. ${ }^{24}$

Evidenciar as regras de constitución do campo da delincuencia xuvenil, no territorio das anormalidades físicas, psíquicas ou morais ${ }^{25}$, puidese ser relevante, dado que é precisamente na procura dunha personalidade delincuente onde continúa comodamente asentado un dos falsos cimentos das novas ciencias do castigo: "a suposición de que é posible avaliar o risco de reincidencia do suxeito en función do peso das observacións dos psicólogos, dos educadores ou dos traballadores sociais" ${ }^{26}$

A análise visionaria foucaultiana en Vixiar e castigar (1996), a propósito da educación na súa dobre función de exame e de vixilancia xerárquica e sancionadora normalizadora, faise tamén evidente. Xa non se trataría de sancionar condutas, senón de garantir a "revisión de si mesmo" que posibilita melloralo e, neste sentido, o equipo técnico emerxe como colectivo profesional chave para deseñar o contido da medida xudicial, e non como advirte Giuliano nunha especie de colonizador, ao poñer en xogo o seu saber, a súa ciencia, a súa verdade e obrigar 0 outro a introxectala. ${ }^{27}$

\footnotetext{
${ }^{23}$ Pedro Dorado Montero, El reformatorio de Elmira. Estudio de Derecho Penal Preventivo (Navarra: Jiménez Gil Editor, 1999), 31 (orixinal publicado en 1908 aprox, Madrid: Librería General de Victoriano Suárez).

${ }^{24}$ Jacques Donzelot, La policía de las familias (Valencia: Pre-textos, 1998, 2. ${ }^{\mathrm{a}} \mathrm{ed}$ ).

25 Julia Varela e Fernando Álvarez-Uría, Arqueología de la escuela (Madrid: La Piqueta, 1991).

${ }^{26}$ Guillermo Rendueles, "Jueces, psiquiatras y asistentes sociales. De matrimonios mal avenidos a menage à trois", Areas. Revista de Ciencias Sociales. Higienismo y Educación (ss. XVIII-XX), n. ${ }^{0} 20$ (2000): 131.

${ }^{27}$ Facundo Giuliano, "Desnudar la razón evaluadora. Elementos para un combate filosófico-educativo", Pensamiento 75, 287 (2019).
} 
Non nos asusta en ningún momento a medida do internamento en réxime pechado, posto que van ter á súa disposición uns psicólogos, uns especializados na problemática do menor que os van recuperar (22-XII-1999, PP).

Na estratexia de afastar do debate político a natureza penal, e pór no seu lugar a finalidade prioritaria de protexer 0 interese do menor, recórrese tamén a unha imaxe de menor delincuente máis próxima á situación de estar en perigo que á de ser perigoso, 0 que á súa vez parecese contradicir a necesidade do carácter penal que se defende.

\begin{abstract}
Tras un mozo infractor sempre hai un dramático problema humano e a constatación do fracaso das estruturas sociais no seu conxunto. A tarefa de buscar un sistema específico que propicie a recuperación do mozo infractor. É algo que a todos os que exercemos responsabilidades públicas nos incumbe (25-II-1999, PP).
\end{abstract}

A maioría dos menores que delinquen, desgraciadamente, teñen múltiples carencias económicas, educativas, familiares. Estas medidas son moi positivas para recuperalos e resocializalos (25-II-1999, PP).

A maioría deles teñen unhas determinadas carencias e o que hai que facer é recuperalos nese sentido (25-II-1999, PP).

Todos os informes do ET tendo en conta as circunstancias persoais, familiares e sociais do menor. Non nos avergoña dicir que son circunstancias sociais, porque sabemos que a contorna do menor o obriga moitísimas veces a delinquir (11-XI-1999, PP).

A utopía da ideoloxía neoliberal leva implícita unha redución da liberdade, unha fenda neta e definitiva entre as circunstancias (sociais) e 0 acto (criminal), as causas e as consecuencias. ${ }^{28}$ No contexto que nos ocupa, resulta evidente como a pirueta neoliberal consiste no específico manexo do concepto de "liberdade de elección" ao conceptualizala como se as estruturas sociais que xeran desigualdades non existisen; pero si existen, e ademais condicionan fortemente a vida das persoas: "vivimos no interior de sociedades xerarquizadas, herdeiras dunha historia, caracterizadas por institucións e organizacións que teñen un peso determinado nos nosos modos de ser, de pensar, de actuar, e de sentir, e que, por tanto, inciden na formación de nosa propia identidade."29

Desde unha ollada multidisciplinar, que alcance os contextos cotiáns destes menores, compróbase facilmente que se trata de suxeitos fráxiles: "forman parte de colectivos que constitúen a máis clara manifestación das fortes tensións que implica, á vez ríxida e flexible, a lóxica social imperante na nosa era do capitalismo avanzado, pondo en evidencia 0 carácter xerárquico e autoritario dos nosos sistemas sociais" ${ }^{30}$ Tamén, que viven procesos de vulnerabilidade social, tal e como é entendida polo sociólogo francés Robert Castel, ao conxugar a precariedade do emprego coa fraxilidade dos soportes de proximidade por carecer de redes de apoio; e que practican a asocial-sociabilidade, entendendo

\footnotetext{
${ }^{28}$ Loïc Wacquant, Las cárceles de la miseria (Madrid: Alianza, 2000).

${ }^{29}$ Fernando Álvarez-Uría e Julia Varela, Sociología de las instituciones. Bases sociales y culturales de la conducta (Madrid: Morata, 2009), 12.

30 Julia Varela e Fernando Álvarez-Uría, Sujetos frágiles. Ensayo de sociología de la desviación (Madrid: Fondo de cultura económica-Paideia,1989), 10.
} 
por tal "as configuracións relacionais máis ou menos evanescentes que non se inscriben, ou que se inscriben de xeito intermitente e problemático, nas institucións recoñecidas". ${ }^{31}$

Baixo este contexto, preguntámonos: pode gozar esta xuventude dun estatuto forte de cidadanía?, poden desenvolver aquelas capacidades que lles permitirían ser unha parte activa, por tanto indignada cando sexa necesario, da sociedade da que forman parte?

En termos da súa educación, conviría colocar as súas necesidades en primeiro plano, pero esta vez coa finalidade de evidenciar as fendas nos seus dereitos, tal e como expón na teoría das capacidades a filósofa Martha Nussbaum:

Capacidade significa 'oportunidade de seleccionar'. A noción de liberdade de elección está, pois, inscrita no concepto mesmo de capacidade [...]. As preguntas que debemos facernos son: que son as persoas realmente capaces de facer e de ser? Cales son as oportunidades reais que a sociedade lles deu para actuar e para elixir?. ${ }^{32}$

Non parece ser este 0 interese de quen defende este proxecto, máis ben pola contra, a cuestión social é substituída pola cuestión persoal, despoxada dos impactos provocados polas fracturas e desigualdades sociais. Neste intento de eludir a cuestión social, situándoa no ámbito da práctica profesional, afastada da economía e da política, faise recaer sobre 0 traballo na comunidade, sobre 0 traballo social, toda a responsabilidade. De novo, asistimos a ese estatuto contraditorio co que nace 0 traballo social neste ámbito, característico da crise dos modelos de intervención social que, como brillantemente advirten Varela e Álvarez-Uría "ten como obxectivo reparar as fracturas sociais - fracturas asignadas a individuos de determinadas clases e grupos sociais relegados- pero sen alterar en profundidade a lóxica de fondo que as xera e xeraba (...) era preciso promover 0 cambio, pero sen alterar a orde; era necesario intervir, pero sen que os especialistas da práctica chegasen a posuír as claves últimas da súa intervención" ${ }^{33}$

A estratexia de individualización dos riscos sociais, unida a grandes doses de pragmatismo, produce un duplo efecto. Por unha banda, os modos de vida desta mocidade son transcritos coma se derivasen exclusivamente da liberdade e da opción persoal, convertendo o destino de clase en destino persoal, isto é, os problemas do sistema en fracaso persoal; co agravante de que se asume como culpa propia moitos dos conflitos que a actual lóxica social xera, ao carecer de claves para tomar conciencia da xénese das desigualdades sociais.

Doutra banda, as necesidades ou as dificultades do pasado son transformadas en riscos para o futuro. Así, non é tanto a reconstrución do pasado como o futuro, 0 que motiva a recollida de información para a posterior valoración. En palabras de Beck

\footnotetext{
${ }^{31}$ Robert Castel, La metamorfosis de la cuestión social. Una crónica del salariado (Barcelona: Paidós, 1997), 438.

${ }^{32}$ Martha C. Nussbaum, Crear capacidades. Propuesta para el desarrollo humano (Barcelona: Paidós, 2012), 51,80

${ }^{33}$ Julia Varela e Fernando Álvarez-Uría, Genealogía y sociología. Materiales para repensar la Modernidad (Buenos Aires: El cielo por asalto, 1997), 170.
} 
Na sociedade do risco, o pasado perde a forza de determinación para o presente. No seu lugar aparece como 'causa' da vivencia e da actuación presentes o futuro, é dicir, algo non existente, construído, ficticio. Hoxe pómonos en acción para evitar, para mitigar, para prever (ou non) os problemas e a crise de mañá e de pasadomañáa. ${ }^{34}$

Esta estratexia contribúe tamén á despolitización, ao manter lonxe das explicacións e propostas o carácter político que as configura. A natureza punitiva, característica da lóxica penal, contamina e redefine a súa natureza tamén educativa ao asumir como principal obxectivo alcanzar unha cultura do consenso e do conformismo social ante a xestión punitiva da pobreza. Parece que esta sexa a súa verdadeira finalidade.

\section{A urxencia do debate pendente: dicir a verdade}

Quen pode crer que penalizando algúns centos de mozos se modificará 0 problema que a súa simple mención se insiste en rexeitar: o afondamento nas desigualdades sociais e a xeneralización da precariedade salarial e social como consecuencia das políticas de desregulación e da deserción económica e urbana do Estado? ${ }^{35}$

Encetamos este milenio coa sensación de formar parte dunha violencia imaxinaria que xera unha grande inseguridade cidadá e que semella apuntar como protagonistas a certo tipo de menores: masculinos, adolescentes, urbanos, violentos que enchen a información vertida polos medios de comunicación e os programas electorais da clase política, provocando un sentido común proclive a lles demandar ás administracións unha maior intervención sobre eles que garanta a sensación de seguridade e a orde social.

0 novo goberno desta vulnerabilidade social, que sofre especialmente a xuventude, á que non se lles outorga un lugar social por non faceren nada útil e non permaneceren en ningunha institución social recoñecida (familia, instituto ou traballo), apóiase en dous alicerces: dunha banda, nun mercado laboral descualificado e desregulado e, da outra, nun aparello xudicial omnipresente que, en nome da educación, reclama a necesidade de esixirlles responsabilidade penal.

A ideoloxía neoliberal atravesa o marco lexislativo actual e, na medida en que 0 Estado de benestar rebaixa e mesmo abandona as súas funcións económicas e sociais desmantelando as súas principais institucións sociais, restrinxe ata tal punto a súa función proteccionista que chega mesmo a reclasificar aquelas minorías que, como é o caso da infancia, outrora acollida baixo o paraugas do proteccionismo, pasa de ser un asunto de asistencia a ser unha cuestión de lei e de orde. Como afirma Castel "o Estado contemporáneo busca outras variables, non económicas, de vulnerabilidade e de incerteza, en que fai descansar a súa lexitimidade, desprazando as preocupacións públicas e as saídas á

\footnotetext{
${ }^{34}$ Ulrich Beck, La sociedad del riesgo. Hacia una nueva modernidad (Barcelona: Paidós, 1998), 40.

${ }^{35}$ Wacquant, Las cárceles de la miseria, 68.
} 
ansiedade individual lonxe das raíces económicas e sociais. A inseguridade cidadá está así de rabiosa actualidade" ${ }^{36}$

Sobre das mutacións derivadas da introdución da ideoloxía neoliberal na xustiza de menores, coincidimos coas sinaladas por Bailleau e Cartuyvels (2011) que reproducimos, aínda que de maneira sintetizada, ao entender que recollen con clareza e lucidez as súas bases teóricas: ${ }^{37}$

1.- Unha inversión da dialéctica da responsabilidade coa aparición do discurso da redución de riscos, asociado a unha lóxica do control, arrastra o polo da responsabilidade dos actores colectivos cara aos individuos e, en consecuencia, modifica o obxectivo da intervención. Desta maneira, a acción educativa ten como fin último protexer a sociedade dos riscos que representa a mocidade en conflito social.

2.- Unha sobreinversión na problemática da seguridade asociada asociado a este colectivo, visualizado como unha ameaza que se suma a outras figuras da inseguridade, como vagabundos, estranxeiros e, máis recentemente, drogadictos ou delincuentes sexuais. No contexto dunha transferencia de angustia expresada por preocupacións de seguridade, prodúcese unha problematización da noción de risco social que leva a asociado a este colectivo, visualizado como unha ameaza como un(s) perigo(s) ligado á persoa e xa non como produto de funcionamento.

3.- Unha focalización seguritaria sobre certos grupos particulares: pandas, bandas urbanas ou outro núcleo duro da delincuencia cuxa importancia numérica é inversamente proporcional á cobertura mediática da que son obxecto. Esta focalización do discurso sobre os grupos en risco opera en beneficio dos grupos máis visibles que ocupan o espazo público ou semipúblico. A cambio, esta énfase en situacións extremas tende a deixar na sombra as categorías intermedias, é dicir, a maioría de mozas e mozos en confito social.

4.- Nosas sociedades protexidas, o rexeitamento ao risco induce a unha práctica punitiva extensiva baseada nun principio de bifurcación. Unha banda, o recurso á tolerancia cero ante conflitos protagonizados por membros de minorías marxinadas percibidas como perigosas con respecto aos valores dominantes das clases medias; pola outra, un trato suave ou prácticas locais de desvío a nivel policial ou xudicial: asociación preventiva e sancións alternativas antes do xuízo, para condutas menos problemáticas.

5.- A psiquiatrización da conduta desviada non é específica da xustiza de menores. Porén, tamén xorde neste campo, formulando un problema de diagnóstico e subliñando novamente as ambigüidades do dúo de penalización e medicalización nun contexto de degradación social, e contribuíndo a unha privatización dos obxectivos da resposta penal, máis orientada á compensación do dano moral, psicolóxico ou material que a unha verdadeira inclusión social.

6.- 0 xurdimento dun ideal de detección e seguimento de grupos en risco con fins de control proactivo. Hoxe, na xustiza de menores, fálase de mapeamento e trazabilidade criminal que permitiría rastrexar a mozos infractores a través de bases de datos computadorizadas.

7.- A evolución da linguaxe utilizada na xustiza de menores: "inputs" e "outputs", "xestores de casos" e clientes, eficiencia e rendibilidade a curto prazo, flexibilidade e adaptabilidade etc. son agora parte do discurso común. 0 carácter performativo da linguaxe traduce aquí a suave contaminación da esfera xudicial pola ideoloxía da xestión e os seus imperativos. A estas transformacións corresponde 0 xurdimento de novos modos formais de intervención na xustiza xuvenil.

\footnotetext{
${ }^{36}$ Castel, La metamorfosis de la cuestión social.

${ }^{37}$ Francis Bailleau e Yves Cartuyvels, "La justice pénale des mineurs en Europe. Un changement de paradigme", Les Cahiers de la Justice 3 (2011): 74-76.
} 
Urxe desvelar as ficcións que impiden aproximarse aos efectos reais da (in)xustiza xuvenil, problematizando aqueles aspectos que os invisibilizan: a concepción psicoloxizada e despolitizada do campo, a predominante ahistoricidade e tamén o lugar actual do dereito, pois ao se concibir non como garante de dereitos fundamentais, senón máis ben como unha enxeñería das relacións sociais, e apoiado nunha nova concepción do suxeito -onde 0 cálculo dos seus intereses tende a substituír a defensa dos seus dereitos-, Antoine Garapon alértanos do perigo que supón que o dereito só dependa da vontade de cada un, isto é, que se volva fráxil ${ }^{38}$.

A política da xustiza xuvenil está moi lonxe de defender os valores que se presentan como de interese xeral, pois 0 carácter penal apártaos doutros que, como 0 marco dos dereitos humanos, poderían converter os delitos en actos merecedores de sancións propias das infraccións administrativas. Un dos asuntos fundamentais para promover un cambio na súa lóxica histórica viría por unha maior transparencia das súas finalidades, de maneira que posibilitara a redefinición dos intereses que debe protexer con maior rigor unha xustiza realmente democrática e, por tanto, que accións e que comportamentos debe penalizar e que outros, en cambio, debe eximir de sanción. Cuestionarse a redefinición da lei nestes termos, posibilitaría exercer un menor reproche discriminatorio e moralista das persoas que xulgan sobre as que son xulgadas, á vez que abriría a posibilidade de ter en conta a voz destas últimas na definición daquilo polo que van ser xulgadas.

Desde unha perspectiva crítica, comprometida cunha sociedade máis xusta, devén imprescindible problematizar a filosofía do actual marco lexislativo destinado a menores en conflito social. Tal e como suxire Foucault, resulta interesante reflexionar sobre o feito de que, aínda que o deber da sociedade é facer que toda a cidadanía se poida recoñecer como suxeito de dereitos e deberes, esta obriga resulta difícil se o sistema que se utiliza é arcaico, arbitrario e inadecuado respecto dos problemas reais que se dan na sociedade. Ante este paradoxo, proponse repensar e formular seriamente a idea dunha lexislación que defina claramente 0 que nunha sociedade realmente democrática poida ser considerado obxecto de castigo, de cara a unha transformación radical que asegure que a xustiza sexa xusta, e non a implantación da cultura punitiva en nome da educación.

\section{Bibliografía}

Álvarez-Uría, Fernando e Varela, Julia. Sociología de las instituciones. Bases sociales y culturales de la conducta. Madrid: Morata, 2009.

Bailleau, Francis e Cartuyvels, Yves. "La justice pénale des mineurs en Europe. Un changement de paradigme". Les Cahiers de la Justice 3 (2011): 67-77.

Beck, Ulrich. La sociedad del riesgo. Hacia una nueva modernidad. Barcelona: Paidós, 1998.

\footnotetext{
${ }^{38}$ Antoine Garapon, "Michel Foucault, visionnaire du droit contemporain", Raisons politiques 52, n. ${ }^{\circ} 4$ (2013): 39-49.
} 
Bauman, Zygmunt. Vidas desperdiciadas. La modernidad y sus parias. Barcelona: Paidós, 2005.

Bergalli, Roberto. "Globalización y control social: post-fordismo y control punitivo". Sistema. Revista de Ciencias Sociale, n. ${ }^{0} 160$ (2001): 107-124.

Bernuz-Beneitez, María José. "L'évolution de la justice des mineurs en Espagne”. Déviance et Société 26, n. ${ }^{0} 3$ (2002): 343-353.

Bernuz-Beneitez, María José. “Justicia de menores española y nuevas tendencias penales: La regulación del núcleo duro de la delincuencia juvenil”. Revista Electrónica de Ciencia Penal y Criminología (2005): 12-23.

Castel, Robert. La metamorfosis de la cuestión social. Una crónica del salariado. BarceIona: Paidós, 1997.

Cerbino, Mauro. Jóvenes en la calle. Cultura y conflicto. Barcelona: Anthropos, 2006.

Donzelot, Jacques. La policía de las familias. Valencia: Pre-textos, 1998, 2. ${ }^{a}$ ed.

Dorado Montero, Pedro. El reformatorio de Elmira. Estudio de Derecho Penal Preventivo. Navarra: Jiménez Gil Editor, 1999 (orixinal publicado en 1908 aprox, Madrid: Librería General de Victoriano Suárez).

Dorado Montero, Pedro. El derecho protector de los criminales. Navarra: Jiménez Gil Editor, 1999 (orixinal publicado en 1915, Madrid: Librería General de Victoriano Suárez).

Foucault , Michel. “¿A qué llamamos castigar?”. Archipiélago, n. ${ }^{\circ} 2$ (1989): 55-63.

Foucault, Michel. Microfísica del poder. Madrid: La Piqueta, 1992, 3. ${ }^{\text {e ed. }}$

Foucault, Michel. Vigilar y castigar. Nacimiento de la prisión. Madrid: Siglo XXI, 1996, 25. a ed.

Garapon, Antoine. "Michel Foucault, visionnaire du droit contemporain". Raisons politiques 52, n. ${ }^{\circ} 4$ (2013): 39-49.

Giménez-Salinas i Colomer, Esther (dir.). Legislación de menores en el siglo XXI: análisis de derecho comparado. Madrid: Consejo General del Poder Judicial, 1999.

Giménez-Salinas i Colomer, Esther (coord.). Justicia de menores: una justicia mayor. Comentarios a la Ley Reguladora de la Responsabilidad Penal de los Menores. Madrid: Consejo General del Poder Judicial, 2000 
Giroux, Henry A. "Pedagogías disruptivas y el desafío de la justicia bajo regímenes neoliberales". Revista Internacional de Educación para la Justicia Social (RIEJS) 4, n. ${ }^{\circ}$ 2 (2015): 13-27.

Gorz, André. Miserias del presente, riqueza de lo posible. Barcelona: Paidós, 1998.

Giuliano, Facundo. “Desnudar la razón evaluadora. Elementos para un combate filosóficoeducativo". Pensamiento 75, n. ${ }^{0} 287$ (2019):1451-1474.

Iglesias Galdo, Ana. Educar e castigar. Unha historia do presente da xustiza de menores en Galicia. A Coruña: Servizo de Publicacións da Universidade da Coruña, 2008.

Jiménez Díaz, María José. "Algunas reflexiones sobre la responsabilidad penal de los menores". Revista Electrónica de Ciencia Penal y Criminología, n. ${ }^{0}$ 17-19 (2015): $1-36$.

Laniel, Richard-Alexandre et Silverman, Max. "Justice néolibérale: quand la logique du marché intègre les institutions judiciaires". Nouvaux Cahiers du socialismo 16 (2016): 43-50.

Larrosa, Jorge, coord., Escuela, poder y subjetivación. Madrid: La Piqueta, 1995.

Lledó, Emilio. Sobre la educación. La necesidad de la literatura y la vigencia de la Filosofía. Barcelona: Taurus, 2018.

Nussbaum, Martha C. Crear capacidades. Propuesta para el desarrollo humano. BarceIona: Paidós, 2012

Rangugni, Victoria. "Algunos aspectos de la 'nueva' justicia de menores”. Panóptico. Revista Monográfica Semestral de Crítica a la Política Criminal, n. ${ }^{\circ} 4$ (1997): 5-11.

Rendueles, Guillermo. "Jueces, psiquiatras y asistentes sociales. De matrimonios mal avenidos a menage à trois". Areas. Revista de Ciencias Sociales, n. ${ }^{0} 20$ (2000).

Varela, Julia e Álvarez-Uría, Fernando (1989). Sujetos frágiles. Ensayo de sociología de la desviación. Madrid: Fondo de cultura económica. Paideia, 1989.

Varela, Julia e Álvarez-Uría, Fernando. Arqueología de la escuela. Madrid: La Piqueta, 1991.

Varela, Julia e Álvarez-Uría, Fernando. Genealogía y sociología. Materiales para repensar la Modernidad. Buenos Aires: El cielo por asalto, 1997.

Wacquant, Loïc. Las cárceles de la miseria. Madrid: Alianza, 2000. 